\section{Biodiversity: there's a role to be played by 'museum-keepers' too}

SIR - Pierre L. Ibisch and colleagues, in Correspondence ("Biodiversity needs the help of global change managers, not museum-keepers" Nature 438, 156; 2005), suggest that conservationists should not focus on single-species approaches in conservation science and practice. But the concept of ecosystem function may be difficult to explain to the general public. Many non-scientific conservationists I know would be more willing to donate money to save 'cute' or impressive animals, such as the Florida panther or the aptly named resplendent quetzal, than to support a theoretical science-based concept such as ecosystem services.

Valuing single species does not rule out using the services aspect of ecosystems. Take ecotourism, for instance: a 'service' as defined by the international Millennium Ecosystem Assessment. A Guatemalan farmer may not care about the resplendent quetzal if he is hungry and destroying more forest will give him more agricultural land. But if the farmer is offered a share in ecotourism projects organizing tours for bird-watchers who wish to see the resplendent quetzal, he may work to preserve the forests.

Many conservation organizations - both applied and science-based - need to focus on a single species in order to raise public money and support. But successful conservation probably needs to include ecosystem function and services to be successful in the long-term. Strategists should ask themselves: What can we do? What can we explain to the broad public? What can we explain to the locals? And what goals can we realistically achieve?

In the end, we need to be both global change managers and museum keepers. Swen C. Renner

Conservation and Research Center, Smithsonian Institution,

National Zoological Park, 1500 Remount Road, Front Royal, Virginia 22630, USA

\section{Climate research opponent is not a friend to science}

SIR - In your Editorial "Taking a stand on animal-rights violence" (Nature 438, 1; 2005) you suggest that US Senator James Inhofe (Republican, Oklahoma) should be applauded for supporting legislation that would make it easier to protect researchers against the threat of violence from animalrights activists.

Some readers might get the impression from your Editorial that Inhofe is a friend of science and scientific research. I strongly disagree with this.

This is the same Inhofe who has told the US Senate, and repeats on his website, that the threat of catastrophic global warming is the "greatest hoax ever perpetrated on the American people". He has worked hard to discredit legitimate research in this area (see http://inhofe.senate.gov/pressreleases/ climateupdate.htm) and has fought to exclude the findings of such research from public policy in the United States. He is co-sponsor of the Bush administration's energy bill (see http:// thomas.loc.gov/cgibin/query/z?c108:s485) which you have previously - and justifiably in my opinion characterized as inadequate (Nature 435, 247; 2005). Inhofe has also taken strong stands against "all types of cloning" and has called embryonic stem-cell research "inconsistent and unreliable and ... unethical” (see inhofe.senate.gov/pressreleases/ content-healthcare.htm).

Any calls to applaud Inhofe should be considered in the context of his broader and in my view much more negative record on scientific issues. William P. Reich

Department of Psychology, Roosevelt University, 430 South Michigan Avenue, Chicago, Illinois 60605, USA

\section{Languages: Europe puts its money where its mouth is}

SIR - Your News Feature "Tongue tied" (Nature 438, 148-149; 2005), drawing attention to endangered languages, was very welcome, but in focusing on US research it overlooked the main work done in this area.

By far the largest investments in endangered-language research have been made by European institutions rather than US ones. Consider, for example, the ongoing investment by the Volkswagen Foundation (\$12.75 million and still rolling) and the Lisbet Rausing Charitable Fund (\$34 million invested through the School of Oriental and African Studies, London).

Even the research on the Siberian language Tofa that was reported in your News Feature was undertaken with Volkswagen funding: it is part of 5 terabytes of data now archived in www.mpi.nl/DOBES at the Max Planck Institute for Psycholinguistics.

In general, I believe that Nature's coverage of language and linguistics is relatively poor - a shame, as this is arguably the most advanced area of research in the humanities and it is developing fast.

Stephen C. Levinson

Max Planck Institute for Psycholinguistics, PO Box 310, 6500 AH Nijmegen,

The Netherlands

\section{Languages: land may speak louder than words}

SIR - Your News Feature "Tongue tied" (Nature 438, 148-149; 2005) shows that field linguists often attempt to save indigenous languages and the information embedded in them by gathering words into dictionaries and grammar texts. This process has an underlying assumption that words mean 'things', and that, once saved, they can be reassembled with the proper grammar to represent experiences.

This perspective is natural for people with a written language, but for many indigenous people, experience bears its own expression and names are 'written' in the terrain. Thus, saving a language may be more dependent on conserving the place in which the language arises.

This became apparent to me in a conversation I had with an indigenous woman from Alaska. Her language, Eyak, is also disappearing: only one old woman now has it as her primary language. While her speech is being recorded and children are encouraged to converse with her, this grandmother is not worried about the demise of Eyak. The elder's advice is to learn the common syntax and grammar of another Athabaskan language, such as Dine, and to return to the land where "the words will be available in the surroundings".

Michael Stocker

Seven Circles Foundation, PO Box 559,

Lagunitas, California 94938, USA

\section{Taxing question of when ethics go up in smoke}

SIR - In News in Brief ("Research centre refuses tobacco-company funding" Nature 438, 271; 2005), you report that the German Cancer Research Centre (DKFZ) has adopted "an ethical code that bans all kinds of funding from tobacco companies". To me this sounds sanctimonious, because - as a member of the country's largest research institution, the Helmholtz Association - the DKFZ is funded almost entirely through taxes.

In 2003, the German federal government received $€ 14.1$ billion (US $\$ 16.6$ billion) in revenue from tobacco taxes, which amounts to $3.4 \%$ of the country's total tax income. As Dr Pötschke-Langer of the DKFZ hopes to "set an example for other German health institutes", I wonder if the DKFZ aims to convince the Helmholtz Association to do without the $€ 74.8$ million that represents $3.4 \%$ of its annual $€ 2$.2-billion funding, or even to renounce $3.4 \%$ of its own budget? Johannes Gerdes

Borstel Research Centre, Division of Tumour Biology, Parkallee 22, D-23845 Borstel, Germany 